\title{
Economic Valuation of Nontimber Forest Products under the Changing Climate in Kilombero District, Tanzania
}

\author{
Chelestino Balama, ${ }^{1,2}$ Suzana Augustino, ${ }^{1}$ Danford Mwaiteleke, \\ Leopord P. Lusambo, ${ }^{3}$ and Fortunatus B. S. Makonda ${ }^{1}$ \\ ${ }^{1}$ Department of Wood Utilization, Sokoine University of Agriculture, P.O. Box 3014, Chuo Kikuu, Morogoro, Tanzania \\ ${ }^{2}$ Directorate of Forest Utilisation Research, Tanzania Forestry Research Institute, P.O. Box 1854, Morogoro, Tanzania \\ ${ }^{3}$ Department of Forest Economics, Sokoine University of Agriculture, P.O. Box 3011, Chuo Kikuu, Morogoro, Tanzania \\ Correspondence should be addressed to Chelestino Balama; balamapc@gmail.com
}

Received 28 April 2016; Revised 19 June 2016; Accepted 26 June 2016

Academic Editor: Kihachiro Kikuzawa

Copyright ( 92016 Chelestino Balama et al. This is an open access article distributed under the Creative Commons Attribution License, which permits unrestricted use, distribution, and reproduction in any medium, provided the original work is properly cited.

\begin{abstract}
Sustainable collection of Nontimber Forest Products (NTFPs) for trade is an appropriate measure to increase people's adaptive capacity against adverse effects of climate change. However, information on the economic value for NTFPs for subsistence use and trade under the changing climate is inadequate, particularly in households around Iyondo Forest Reserve (IFR), in Kilombero District, Tanzania. The study identified and quantified NTFPs used for subsistence and trade, estimated its economic value, and examined factors influencing supply of NTFPs at household level. Data were collected through Focus Group Discussions, key informant interviews, questionnaire survey of 208 sample households, and spot market analysis to randomly selected NTFPs collectors, sellers, and buyers. The study identified 12 NTFPs used for subsistence and trade, which was evaluated in terms of the mean annual value per household. The mean annual value of the identified NTFPs ranged from TZS 4700 to 886600 . The estimated economic value of the studied NTFPs was TZS 51.4 billion (USD 36 million). The supply of NTFPs at household level was influenced by distance to the forest, change in forest management regime, seasonality, and change in rainfall pattern. NTFPs around IFR have high economic value which portrays the potential of developing them to enhance households' adaptive capacity against climate change adverse effects.
\end{abstract}

\section{Introduction}

Nontimber Forest Products (NTFPs) play a significant and critical role in improving livelihoods to a large part of the world's population [1-3] particularly at the current change in climate. Climate related hazards and more subtle trends interact with nonclimatic stressors such as multiple deprivations, market shifts, conflict and insecurity, and loss of access to resources to exacerbate the vulnerability of agricultural systems $[4,5]$. While not all the poor are equally affected by such stressors, nonpoor groups can also be vulnerable. Rural populations living in poverty often suffer more than others when extreme climate change events like heavy rains and floods, prolonged dry spells, and extreme heat occur [5]. These climate extreme events have been noted to affect much natural asset, particularly agriculture which is the main livelihood of the rural people in Africa [6-8].

Agricultural production and food security in many parts of Africa are likely to be severely compromised by climate change, in particular by damaging high temperatures and the greater incidence of drought [9]. Agriculture is a significant household activity in many countries of Sub-Saharan Africa because the majority of the people who live in rural areas depend on both substance and local trade in agricultural produce [8]. Much of the cropland is rain-fed and is therefore vulnerable to climate change that is characterised by drought and floods that frequently cause crop failure. Households with low adaptive capacity are thought to be more vulnerable to the adverse effects of climate change, which contribute to the loss of their natural resources $[10,11]$. According to URT 
[12], the change in temperature and precipitation patterns has led to increased risk of recurrent droughts and devastating floods and has been threatened with biodiversity loss, an expansion of plant and animal diseases, and a number of potential challenges for public health. Such recurrent risks have affected the main conventional livelihoods of the households, thus increasing reliance on NTFPs for both subsistence use and cash income [13]. Increased reliance on NTFPs calls for economic valuation for rational planning of the resource. The economic value concept entailed the value of the goods that would be missing if a forest suddenly disappeared [14]. This can also be referred to as the total cost to households in the study area if the forest is completely removed or total access is denied.

The need to identify the economic value of NTFPs in rural households in the developing countries is gaining importance in both the conservation and development phenomena [1518]. NTFPs are reported to significantly contribute to economic benefits of rural households in developing countries in three major ways: first, providing domestic subsistence and consumption requirements [19] for increased disposable income to the household; second, serving as an immediate safety net against experienced climate change adverse effects, constituting an important part of adaptive capacity [11, 20, 21]; and, third, contributing to direct monetary benefits through trade $[17,22]$. Studies show that most attempts to valuate NTFPs have been undertaken at the local level [22]. To estimate the contribution of NTFPs to social and economic well-being, their valuation at broader scales is acclaimed as pertinent $[23,24]$, due to being among the effective climate change adaptation strategies in Africa [13]. Heubach et al. [18] in Northern Benin argued that species with high economic value can buffer possible cash shortfalls; this especially holds true for women since they are the main collectors and traders of NTFPs.

Sustainable collection of NTFPs for trade is expected to increase the adaptive capacity of households in rural Tanzania to climate change by majority of people including those surrounding IFR. Schaafsma et al. [25] revealed that local people bear economic loss if they are denied of collection of NTFPs. Similarly, Msalilwa et al. [26] revealed that the demand for some NTFPs was increasing by forest dependent households around New Dabaga Ulongambi Forest Reserve in Kilolo District more than it used to be 30 years ago, due to climate change effects. This is also the case for the households around IFR in Kilombero District where demand of NTFPs by households to increase resilience to adverse effects of changing climatic conditions is significantly eminent [27]. However there is increasing demand of NTFPs, and information on its economic value for subsistence use and trade in terms of benefits and its importance to livelihoods of households under the changing climate is inadequate in Tanzania including IFR and its surroundings. Also, most of the NTFPs are collected, traded, and consumed outside the cash economy and therefore are not adequately captured in national economy statistics [8]. Lack of economic contribution of NTFPs to the GDP has led to insufficient recognition in national planning for local livelihoods adaptation measures. There is a growing need at national and international policy levels for projections at large spatial scales of the economic values that households derive from forests, including the collection of NTFPs [28]. It is against this background that the study to estimate economic value of NTFPs in IFR and its implication on adaptation to climate change in Kilombero District, Tanzania, was designed. Specifically the study identified and quantified NTFPs that are used for subsistence and trade, estimated their economic value, and examined factors influencing their supply in the study area. Estimating the economic value of NTFPs has advantage since it helps to ascertain the true value of the standing forest, thus leading to more rational decisions about the alternative uses of the forest $[29,30]$. The results from this study are also useful to various stakeholders in the overall implementation of the National REDD+ strategy in Tanzania to enhance the adaptive capacity of households through promotion and development of NTFPs as carbon cobenefits for sustainable management of natural resources. Ferreira et al. [31] argued that sustainable management of NTFPs plays two potential roles in REDD+. Firstly, it helps to reduce NTFPs extraction that contributes to forest degradation and associated emission. Secondly, it enables sustainable exploitation of NTFPs that can contribute to reducing degradation and deforestation caused by other factors, through (a) increasing value of the forests and thereby reducing pressure on them and (b) providing alternative sources of income to activities that deplete forest carbon stock. However, the potential for increasing the sustainability of NTFPs use depends on the products extracted and the characteristics of the species and the forests [31]. For example, harvesting of dead wood, fruits, seeds, and mushrooms has been pointed out to have the high potential for sustainability.

\section{Methodology}

2.1. Study Area. Kilombero District is among the six districts of Morogoro region [32]. A large part of Kilombero District is located in a floodplain area, which is important for main economic activities of the people including agriculture, livestock keeping, fishing, and wild game hunting [33]. However, these livelihood activities have been affected by the recurrent stresses due to changing climatic conditions including floods, dry spells during rainy season, extreme heat, and some other stresses, which have adverse effects on the livelihoods of the people [34-36]. Specifically the study was conducted in four villages of Kilombero District, namely, Mpofu, Igima, Njage, and Mngeta (Figure 1). The choice of the study area was based on villages that surround Iyondo Forest Reserve (IFR) which is part of Kilombero Nature Reserve (KNR) at the moment with resources important for increasing resilience of the households against adverse effects of climate change. Other villages that surround the reserve are Mbingu and Mchombe.

The climate in the study area is marked by wet and dry seasons which are further distinguished into four subseasons, namely, hot wet season from December to March, cool wet season April-June, cool dry season July-August, and hot dry season September-November. The area receives between 1200 and $1800 \mathrm{~mm}$ of rainfall per year and temperatures range from $26^{\circ} \mathrm{C}$ to $32^{\circ} \mathrm{C}[38,39]$. However, the rains are currently unpredictable, whereby the onset and cessation are 


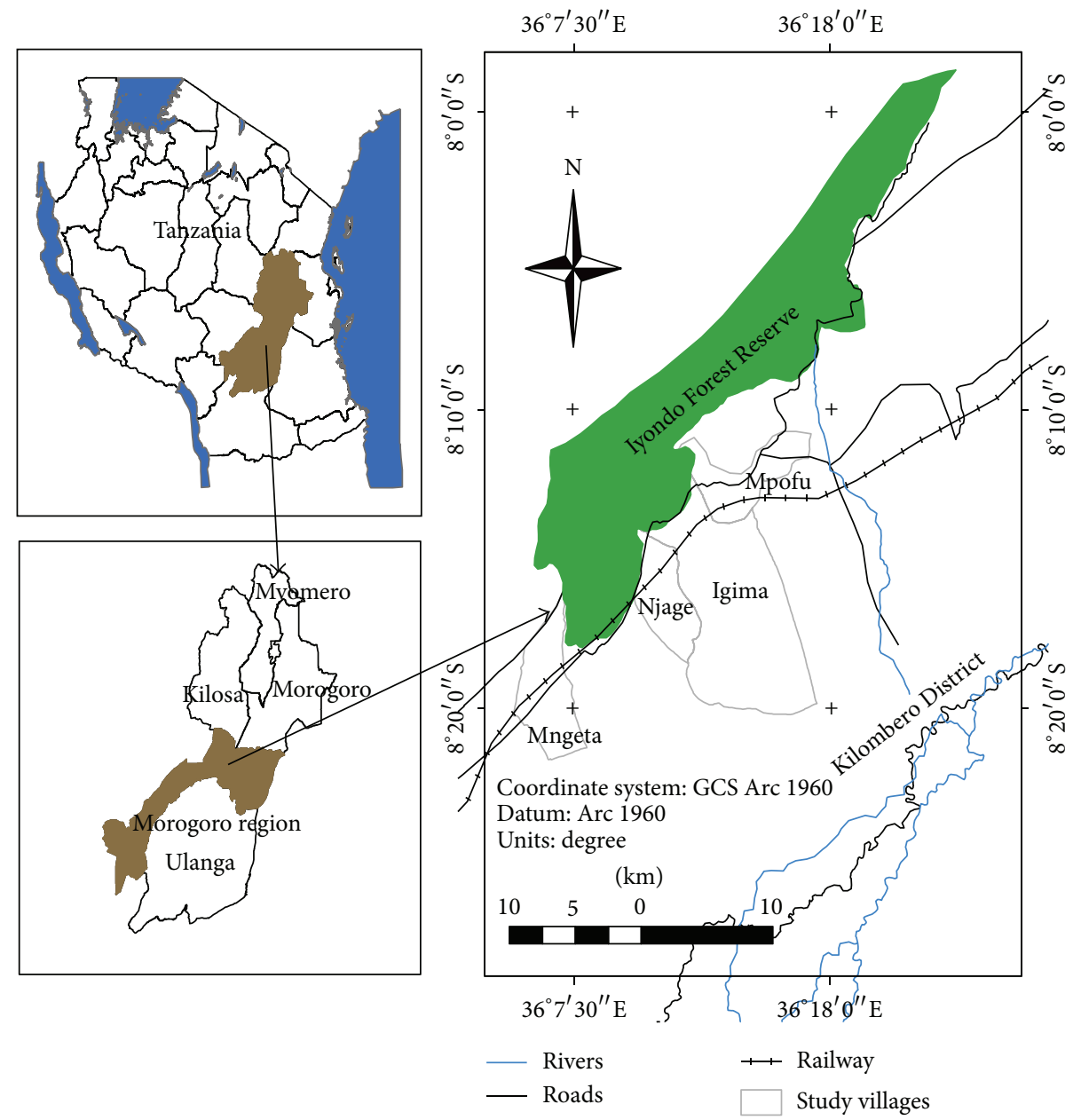

FIGURE 1: Map showing location of study villages in Kilombero District, Tanzania. Source: NBS [37].

inconstant [27]. The general topography in the study villages is a flat land with mean elevation ranging from 274 to $358 \mathrm{~m}$ a.s.l. Soils are mainly loamy and sandy while some cotton black soils in flooded areas are found. In hilly areas, the soils are sandy loam over crystalline rocks [40]. The main vegetation found in the study area is Miombo woodlands [40], with some open grassland areas in the floodplains [33].

Access to the study villages is through an earth road running from Ifakara Town to Mlimba as well as the railway line of Tanzania-Zambia Railway Authority (TAZARA) that extends from Dar es Salaam (Tanzania) to Kapiri Mposhi (Zambia). Ethnic groups (Table 1) are seemingly diverse but still share similar livelihoods and sociocultural norms [32]. The main economic activities in the study area are agriculture (crops grown are in Table 1) and livestock keeping.

\subsection{Data Collection. Data were collected using Focus Group} Discussions (FGDs), key informant interviews, household questionnaires survey, and spot market analysis. FGDs are aimed at capturing information on available NTFPs in the area, places where they are collected, unit value of each NTFP, main sources of household income, and historical use of
NTFPs. FGDs comprised 10-12 people in each village, aged 18 years and above, representing various livelihoods and sex. Key informant interviews were conducted to village leaders, village elders, NTFPs vendors, herbalists (i.e., traditional healers and medicinal plant sellers), village environmental committee members in the respective villages to supplement data collected through FGDs, and household questionnaire survey. Key informants were purposely selected based on their experience on the subject matter and special level of information they provided. Moreover, household survey was conducted in four villages that were purposely selected on the basis of their relative distance from the forest for questionnaire interviews. Moreover, household survey was conducted in four villages, whereby a total of 208 households were randomly selected based on sampling intensity of 5\% (Table 2).

Pilot testing of the survey instruments was conducted among 30 randomly selected households prior to implementation of the survey and then the questions were adjusted accordingly. Pilot testing was carried out in order to improve validity of the survey tools [41]. The questionnaires were then administered to randomly selected households in each village to capture information on quantity of NTFPs collected, pattern of use (subsistence or trade), places where NTFPs are 
TABLE 1: Some physical and demographic characteristics of the study area.

\begin{tabular}{|c|c|c|c|c|}
\hline Characteristics & Mpofu & Igima & Njage & Mngeta \\
\hline Geographic position & $08^{\circ} 12^{\prime} 57^{\prime \prime} \mathrm{S} ; 36^{\circ} 14^{\prime} 33^{\prime \prime} \mathrm{E}$ & $08^{\circ} 15^{\prime} 59^{\prime \prime} \mathrm{S} ; 36^{\circ} 13^{\prime} 27^{\prime \prime} \mathrm{E}$ & $08^{\circ} 15^{\prime} 26^{\prime \prime} \mathrm{S} ; 36^{\circ} 10^{\prime} 08^{\prime \prime} \mathrm{E}$ & $08^{\circ} 19^{\prime} 24^{\prime \prime} \mathrm{S} ; 36^{\circ} 06^{\prime} 28^{\prime \prime} \mathrm{E}$ \\
\hline Mean altitude (m) & 295 & 274 & 312 & 387 \\
\hline Population of people ${ }^{*}$ & 3123 & 5146 & 3402 & 5116 \\
\hline $\begin{array}{l}\text { Average household } \\
\text { size }^{* *}\end{array}$ & 4.72 & 4.82 & 4.78 & 4.93 \\
\hline Crops grown & $\begin{array}{l}\text { Main (banana, maize, rice); } \\
\text { others (sesame, cocoa, } \\
\text { sunflower, cassava) }\end{array}$ & $\begin{array}{l}\text { Main (rice, banana); others } \\
\text { (maize, cassava) }\end{array}$ & $\begin{array}{l}\text { Main (rice, banana, maize); } \\
\text { others (sesame, cassava) }\end{array}$ & $\begin{array}{l}\text { Main (rice, maize); others } \\
\text { (cassava, banana) }\end{array}$ \\
\hline Ethnic groups & $\begin{array}{c}\text { Main (Hehe, Nyakyusa, } \\
\text { Bena, Ndali); others } \\
\text { (Sukuma, Makua, Kerewe, } \\
\text { Gita, Ndamba, Pogolo, } \\
\text { Nyamwezi, Haya, Safwa, } \\
\text { and Kinga) }\end{array}$ & $\begin{array}{l}\text { Main (Ndamba, Hehe, } \\
\text { Nyakyusa); others (Bena, } \\
\text { Sukuma, Pogolo, Kerewe, } \\
\text { Chaga, and Nyamwezi) }\end{array}$ & $\begin{array}{l}\text { Main (Hehe, Bena, } \\
\text { Nyakyusa, Ndamba); others } \\
\text { (Sukuma, Pogolo, Kerewe, } \\
\text { Gita, Chaga, and Matumbi) }\end{array}$ & $\begin{array}{l}\text { Main (Ndamba, Hehe, } \\
\text { Bena, and Sukuma); others } \\
\text { (Pogolo, Nyakyusa, Ndali, } \\
\text { Luguru, Kinga, and } \\
\text { Matumbi) }\end{array}$ \\
\hline
\end{tabular}

${ }^{*}$ Housing and population census of 2012 [32]; ${ }^{* *}$ number of households in each village is indicated in Table 2.

TABLE 2: Sample size distribution in the study area.

\begin{tabular}{lcccc}
\hline Village & Relative distance & Number of households & Sampling intensity & Sample size $(n)$ \\
\hline Mpofu & Very close* $^{*}$ & 714 & 0.05 & 36 \\
Igima & Far $^{* *}$ & 1282 & 0.05 & 64 \\
Njage & Very close & 868 & 0.05 & 43 \\
Mngeta & Far & 1293 & 0.05 & 65 \\
\hline Total & & 4157 & & 208 \\
\hline
\end{tabular}

${ }^{*}$ These are villages whose households were very close to IFR with a walking distance of about $0.2 \mathrm{~km}$.

${ }^{* *}$ These are villages whose households were relatively far from the IFR with a walking distance of about 5 and $10 \mathrm{~km}$ for Igima and Mngeta, respectively.

collected, unit value of each NTFP, and factors influencing supply of NTFPs at household level.

Spot market analysis was carried out using a checklist which was randomly administered to collectors, sellers, and buyers in the local markets and around households where NTFPs were being displayed for sale. Information collected included unit value/market price and average amount of NTFPs collected per week and their potential in enhancing adaptive capacity to climate change at household level.

Secondary data on climate, mainly rainfall from the Tanzania Meteorological Agency (TMA) for a span of 30 (19802010) years, were used to show trend of rainfall in the study area.

2.3. Data Analysis. Qualitative data collected through FGDs and key informant interview were analysed using content analysis. The data were categorized into meaningful units and themes in keeping with the research questions. The summaries of the narrations were used in the discussion. Quantitative data including amount of NTFPs collected and unit value of NTFPs were coded, processed, and descriptively analysed using Statistical Package for Social Sciences (SPSS) computer software tools. Descriptive statistics generated percentage and means on demographic and socioeconomic characteristics; quantities and values of direct use benefit from NTFPs collected factors influencing supply of NTFPs. The results were summarized in tables to simplify interpretation. The market price method was used to value NTFPs.
Market price is an approach that is commonly used to value environmental goods and services that have established markets [17, 30]. Quantification of identified NTFPs was calculated in terms of mean annual values as indicated in the following:

$$
a_{m}=Q_{m} * V_{u}
$$

where $a_{m}$ is mean annual value in TZS, $Q_{m}$ is mean annual quantity of NTFPs collected per household $(\mathrm{Kg})$, and $V_{u}$ is unit value in TZS per unit measure. This is an annual average price of a particular NTFP from different dealers in study area. The calculated unit value is assumed to be applied throughout the year. It also makes consideration of seasonal price fluctuation.

The following discounting formula was used to estimate the economic value of NTFPs that was expressed in terms of annual present value $(\mathrm{PV})$ :

$$
\mathrm{PV}=\frac{a\left[(1+r)^{n}-1\right]}{\left[r(1+r)^{n}\right]},
$$

where PV is present value of NTFPs in TZS, $a$ is the estimated annual actual value of NTFPs in TZS, and $r$ is social discount rate. The discount rate was useful in this study because the study dealt with benefits of the forests and woodlands which are public property and attached to community values that count more than individual preference. Therefore, the social 
discount rate chosen was $10 \%$ which is recommended by the World Bank [42]. $n$ is time horizon (infinity for the context of this study).

Assuming continuous flow of benefits to the community from the forest and woodlands for infinity annual series, then " $n$ " in (2) approaches to infinity and a useful formula becomes

$$
\mathrm{PV}=\left[\frac{a}{r}\right] .
$$

From (3), the annual actual value " $a$ " was calculated as given in

$$
a=Q_{m} * V_{u} * P_{r} * H_{t},
$$

where $P_{r}$ are proportions of respondents using the product in percentage and $H_{t}$ is total number of households in the study area. In this case a total of 8308 households from all villages (six) surrounding the IFR were used.

In calculating the economic values of NTFPs, the following key assumptions and considerations were adhered to:

(i) Assume that each NTFP collected had the same market value.

(ii) Economic value of NTFPs was in terms of gross values because estimation of cost of harvesting of each NTFP separately seemed very involving. This is because of the nature of trips into forest and woodlands, which were multipurpose, like doing it along with farming activities and some of the NTFPs were collected jointly, for example, extraction of withies and ropes, so estimating them could lead to double counting. According to Morse-Jones et al. [43] double counting may occur where competing ecosystem services are valued separately and the values aggregated or where an intermediate service is first valued separately but also subsequently through its contribution to a final service benefit.

\section{Results and Discussions}

3.1. Characteristics of the Respondents. The characteristics of respondents included were age, sex, marital status, education level, and occupation (Table 3). These characteristics were reported to influence behaviour of respondents in collection and trading of NTFPs. Results showed that $65 \%$ of the respondents were aged between 31 and 60 years (Table 3 ). This showed that the majority of the respondents were physically and economically active to engage in various production activities including collection of NTFPs. Studies, for example, Dolisca et al. [44] and Tazeze et al. [45], show that age is significantly related to farmer's decisions during adoption to climate change adaptation strategies. The same authors also reported that as age of the household head increases the person is expected to acquire more experience in weather forecasting that helps in increasing the likelihood of practicing different adaptation strategies to climate change including collection and trade of NTFPs. This causal relationship between age and ability to decide and practice various adaptation options including collection of NTFPs was also
TABLE 3: Socioeconomic characteristics of the respondents in the study area.

\begin{tabular}{lc}
\hline Socioeconomic attribute & $\begin{array}{c}\text { Response (\%) } \\
n=208\end{array}$ \\
\hline Age (years) & 28 \\
$18-30$ & 65 \\
$31-60$ & 7 \\
Above 60 & \\
Sex & 39 \\
Male & 61 \\
Female & \\
Marital status & 2 \\
Single & 91 \\
Married & 4 \\
Widow/widowed & 3 \\
Separated/divorced & \\
Education level & 13 \\
No formal education & 83 \\
Primary level & 3 \\
Secondary level & 1 \\
Postsecondary education & \\
Occupation & 35 \\
Peasant farming & 3 \\
Petty trade & \\
Salaried employment & \\
\hline & \\
\hline & \\
\hline
\end{tabular}

revealed during FGDs whereby people aged 60 years and above declared to have fewer adaptation strategies than youths. This is because most of the livelihood activities were claimed to be carried out manually/physically in such a way that they did not afford.

The results further showed that $61 \%$ of respondents were women and 39\% were men. However, it should be noted that all women interviewed were not necessarily heads of households because in some instance heads of households (men) were not available at homes during interview for various reasons, so they were represented by their wives. During FGDs, it was revealed that collection of NTFPs like mushrooms and firewood as among the coping strategies for climate change involves both men and women. Participants in the FGDs further argued that, in the past, collection of such products was only done by women, whereby men were mainly involved in game meat hunting, collection of building poles, and timber harvesting. This implies that current collection of NTFPs aims not only for subsistence use but also for cash income generation which is used for various households needs. Regarding marital status, about $91 \%$ of the respondents were married (Table 3), implying that households with married couples have ability to carry out different livelihoods activities including collection and trade of NTFPs.

Eighty-three per cent of the respondents had primary education, whereas few of them had secondary and postsecondary education (Table 3). As most of the respondents were 
TABLE 4: Mean annual value of identified NTFPs in the study area.

\begin{tabular}{|c|c|c|c|c|c|c|}
\hline \multirow[t]{2}{*}{ Products } & \multirow[t]{2}{*}{ Units } & \multicolumn{2}{|c|}{$\begin{array}{c}\text { Mean annual quantity per } \\
\text { household }\end{array}$} & \multirow{2}{*}{$\begin{array}{c}\text { Mean annual } \\
\text { quantity per } \\
\text { household }\end{array}$} & \multirow{2}{*}{$\begin{array}{l}\text { Unit value } \\
\text { (TZS) }\end{array}$} & \multirow{2}{*}{$\begin{array}{c}\text { Mean annual } \\
\text { value (TZS) per } \\
\text { household }\end{array}$} \\
\hline & & Subsistence & Trade & & & \\
\hline Firewood & Head load & $115(83)$ & $328.3(12)$ & 443.3 & 2000 & 886600 \\
\hline Bush meat & Kgs & $45.3(36)$ & $110(38)$ & 155.3 & 3000 & 465900 \\
\hline Wild mushroom & Kgs & $68(36)$ & $224(21)$ & 292 & 1000 & 292000 \\
\hline Medicinal plants & Kgs & $2.6(36)$ & $26.3(2)$ & 28.9 & 8000 & 231200 \\
\hline Honey & Litres & $4.6(10)$ & $21.1(22)$ & 25.7 & 6000 & 154200 \\
\hline Poles & Pieces & $27.3(30)$ & $52(5)$ & 79.3 & 1000 & 79300 \\
\hline Thatch grass & Head load & $26(45)$ & $25(28)$ & 51 & 1000 & 51000 \\
\hline Ropes & Bundles & $2(23)$ & 0 & 2 & 8000 & 16000 \\
\hline Wild vegetables & Kgs & $28.65(70)$ & 0 & 28.65 & 500 & 14325 \\
\hline Withies & Bundles & $2.5(25)$ & 0 & 2.5 & 5000 & 12500 \\
\hline Wild fruits & Kgs & $19.7(51)$ & 0 & 19.7 & 400 & 7880 \\
\hline Tool handles & Pieces & $3.7(51)$ & $10(11)$ & 4.7 & 1000 & 4700 \\
\hline
\end{tabular}

Number in parenthesis is a proportion of respondents (\%) of the households.

A unit of head load for firewood and thatch grass was equivalent to $16.55 \pm 3.33$ and $14.12 \pm 3.19 \mathrm{Kg}$, respectively.

literate, it is shown that they are aware of various livelihoods related to climate change adaptation including collection and trade of NTFPs. A study by Tazeze et al. [45] found that literate farmers are more likely to respond to climate change by making best adaptation options based on preferences and influences individual decision making. On the other hand, the majority of respondents (95\%) were peasant farmers followed by few respondents with other occupations. This implied that farming was the main economic activity in the study area which is claimed not stable because of climate change adverse effects. This further implied that households were probably engaged in other livelihoods like collection and trading of NTFPs in order to gain income.

3.2. Identified and Quantified NTFPs. Results showed that 12 NTFPs ranging between food products, firewood, and construction materials were collected and traded by households living adjacent to IFR. The identified and quantified NTFPs in the study area were firewood, bush meat, wild mushrooms, medicinal plants, honey, poles, thatch grass, ropes, wild vegetables, withies, wild fruits, and tool handles (Table 4). The mean annual value of the identified NTFPs ranged from TZS 4700 to 886600 . Firewood had the highest mean annual value followed by others (Table 4 ). The NTFPs were collected mainly from farmlands and village forests and illegally from IFR for some NTFPs like dried firewood, mushrooms, wild vegetable, and wild fruit. The most dominant NTFPs in terms of mean annual value per household were firewood, bush meat, wild mushroom, medicinal plants, and honey.

The majority ( $83 \%$ ) of respondents collected firewood for subsistence and trade, respectively (Table 3). A mean of 443.3 head loads per household was collected, which had a mean annual value of TZS 881200 (Table 4). The annual mean head loads of firewood recorded in this study were higher than 98 and 99 head loads recorded by Msemwa [46] in Kilosa District and Kilonzo [47] in households around Nyanganje
Forest Reserve in Kilombero Districts, respectively. The observed difference could be attributed by the use pattern of the product, as this study recorded quantities of firewood used for subsistence and trade, while past studies recorded subsistence use only. Also higher mean head loads for trade could probably be associated with reduced income of the households from conventional sources, mainly agriculture, due to the current adverse effects of climate change.

On the other hand, bush meat hunted from IFR was for subsistence (36\%) and trade (38\%). A mean annual value of TZS 465900 per household was obtained from $155.3 \mathrm{~kg}$ of bush meat per year. Only few respondents reported to collect bush meat because this activity was done illegally in the IFR, and thus only few people dared to go for hunting. Even though there were few hunters of bush meat, they collected bush meat in high quantities because it fetched relatively low unit value of TZS 3000 per $\mathrm{kg}$ (Table 4) compared to TZS 6000 for meat from cattle. Larger proportion of the collected bush meat was traded (110 kg per year) entailing that hunting for the bush meat was aimed for cash income. During FGDs it was noted that trading for bush meat started in 2000 for income generation due to unpromising yields from conventional livelihoods including agriculture. This could probably be influenced by adverse effects of climate change in the study area. The mean annual amount of bush meat collected in the study area was relatively higher than that reported by Masam [48] who found about $11 \mathrm{Kg}$ of bush meat being consumed by $73 \%$ of the respondents living adjacent to New Dabaga Ulongambi Forest Reserve, in Kilolo District. Hamza et al. [49] reported a mean of $60.1 \mathrm{Kg}$ was consumed per household annually to villages surrounding Mgori Forest Reserve, Singida Rural District. Differences in consumption of wild meat could be caused by availability, abundance, accessibility to the resources, reluctance of household probably in giving true figures, and sometimes religious beliefs. The study has revealed large amount of bush meat being illegally 
hunted from IFR. The IFR is now part of the Kilombero Nature Reserve (KNR) where its management policy does not allow anthropogenic activities in the reserve. Continued illegal hunting of bush meat indicates high demand of animal protein by the households; this could also be due to insufficient alternative sources. Policies governing conservation of the reserve could be reviewed in order to regulate bush meat hunting. Also it is important for the households to diversify sources of protein through livestock keeping.

On the other hand, wild mushroom was collected for both subsistence and trade by $36 \%$ and $21 \%$ of the respondents, respectively. The mean annual value of TZS 292000 per household was obtained from $155.3 \mathrm{~kg}$ of wild mushroom per household (Table 3 ). The current amount of mushrooms used for subsistence and traded in this study was much higher than that reported by Paulo [50] in Kilwa District, whereby annual average of about $29 \mathrm{~kg}$ was collected. Other results within Tanzania have reported different findings; for instance, Msemwa [46] reported that 29\% of households in Kilosa District collected wild mushrooms from general land at an average quantity of $7.5 \mathrm{~kg}$ per household per year. Similarly, Kilonzo [47] reported $71 \mathrm{~kg}$ of wild mushrooms collected annually per household (66\%). Higher quantities regarding mushrooms collection in this study as compared to other studies in Tanzania could probably be due to the fact that the current study included mushrooms that were collected for both subsistence and trade. On the other hand, about $36 \%$ of the respondents declared to collect medicinal plants for subsistence use, and only few (2\%) collected them for trade. A mean annual value of TZS 231200 per household was obtained from $28.9 \mathrm{~kg}$ of medicinal plants per household. Results from other studies in Tanzania including the study by Masam [48] in Kilolo District reported an average of $38 \mathrm{~kg}$ being collected per year per household, while Paulo [50] in Kilwa District reported an estimate of $13 \mathrm{~kg}$ per year per household. Similarly Msemwa [46] recorded a mean annual value of TZS 22088 of medicinal plants per household in Kilosa District. Variation in collection could be due to existing local knowledge on the available medical plants, accessibility to the products, and religious beliefs, since some respondents associate use of medicinal plants with witchcraft.

Honey was also collected for both subsistence and trade by $10 \%$ and $22 \%$ of the respondents, respectively. The mean annual value of TZS 254000 per household was obtained from $25.7 \mathrm{~kg}$ of honey per household (Table 3 ). The amount of honey collected per year in this study was much higher than those reported by Msemwa [46] and Paulo [50] which were 11.76 and $15 \mathrm{~kg}$ with mean annual values of TZS 14739 and 10500 per household in Kilosa and Kilwa Districts, respectively. The differences in mean annual value between the current and previous studies could be due to unit value of the honey. In the current study, unit value was TZS 6000 per $\mathrm{kg}$ while that by Msemwa [46] was TZS 1755 per kg. The high unit value of honey observed in the study is a reflection of scarcity and high marketing potential of bee products in Kilombero District which could also be linked to current adverse effects of climate change on households' livelihoods.
3.3. Economic Value of NTFPs. Economic value of the studied NTFPs for both subsistence and trade at a discounting rate of $10 \%$ was TZS 51.4 billion, equivalent to USD 36 million (Table 5). The economic value from the NTFPs indicated how households can increase their adaptive capacity through sustainable use of the resources for improved livelihoods. The economic value from the current study was relatively low compared to the one obtained by Schaafsma et al. [28] working around Eastern Arc Mountains which was TZS 59 billion (USD 42 million) for firewood, charcoal, thatch grass, and poles. However, it was high compared to URT [14] for Uluguru Catchment Forest reserves, in Morogoro region where TZS 39.6 billion (USD 39.6 million) for firewood, poles, and withies was obtained. The differences between the three studies could probably be due to the differences in market prices of the products as attributed by time differences, number of NTFPs dealt, and population size of the people in the study areas. The economic value of NTFPs from this study was mainly contributed by firewood (46\%) followed by bush meet $(28 \%)$, mushrooms (11\%), thatch grasses (4\%), medicinal plants (3\%), and others (8\%). Other NTFPs studied that had economic value included honey, poles, wild vegetable, tool handles, wild fruits, withies, and ropes. However, the present study discussed the most dominant five NTFPs.

In this study, the annual present value of firewood for both subsistence and trade, at discount rate of $10 \%$, was TZS 23.5 billion which was equivalent to USD 11.3 million (Table 5). High contribution (72\%) of the annual present value was from firewood used for subsistence and the remaining proportion was for trade. This indicated that firewood use pattern is under transition from subsistence to trade for generating income. The annual present value from this study was lower than those reported by URT [14] and Schaafsma et al. [28] which were TZS 32.6 billion (USD 32.6 million) and 36 billion (USD 25.33 million) from households around Uluguru Catchment Forest reserves, in Morogoro region and the Eastern Arc Mountains, respectively. Low value obtained from this study compared to the two past studies could probably be due to large number of populations involved in their study as well as availability and access to the firewood. The findings further implied that firewood as part of the natural capital asset had economic value which is significant. As the economic value of firewood was significantly high, this calls for households to be assisted in establishment of woodlots of fast growing tree species for firewood production. In future such woodlots can be used as collateral to various financial institutions and access development funds, therefore increasing adaptive capacity of households to adverse climate change effects as well as extreme events.

On the other hand, the present study recorded high annual present value compared to TZS 4.6 billion (USD 4.2 million) reported by Msemwa [46] from forests on general land in Kilosa District. The current findings were also higher than that reported by Kilonzo [47] from Nyanganje Forest Reserve in Kilombero District. The differences observed could be attributed by the average amount of head loads collected per year per household. Another plausible reason could probably be change in use pattern from subsistence to trade of firewood for income generation in order to carter for 


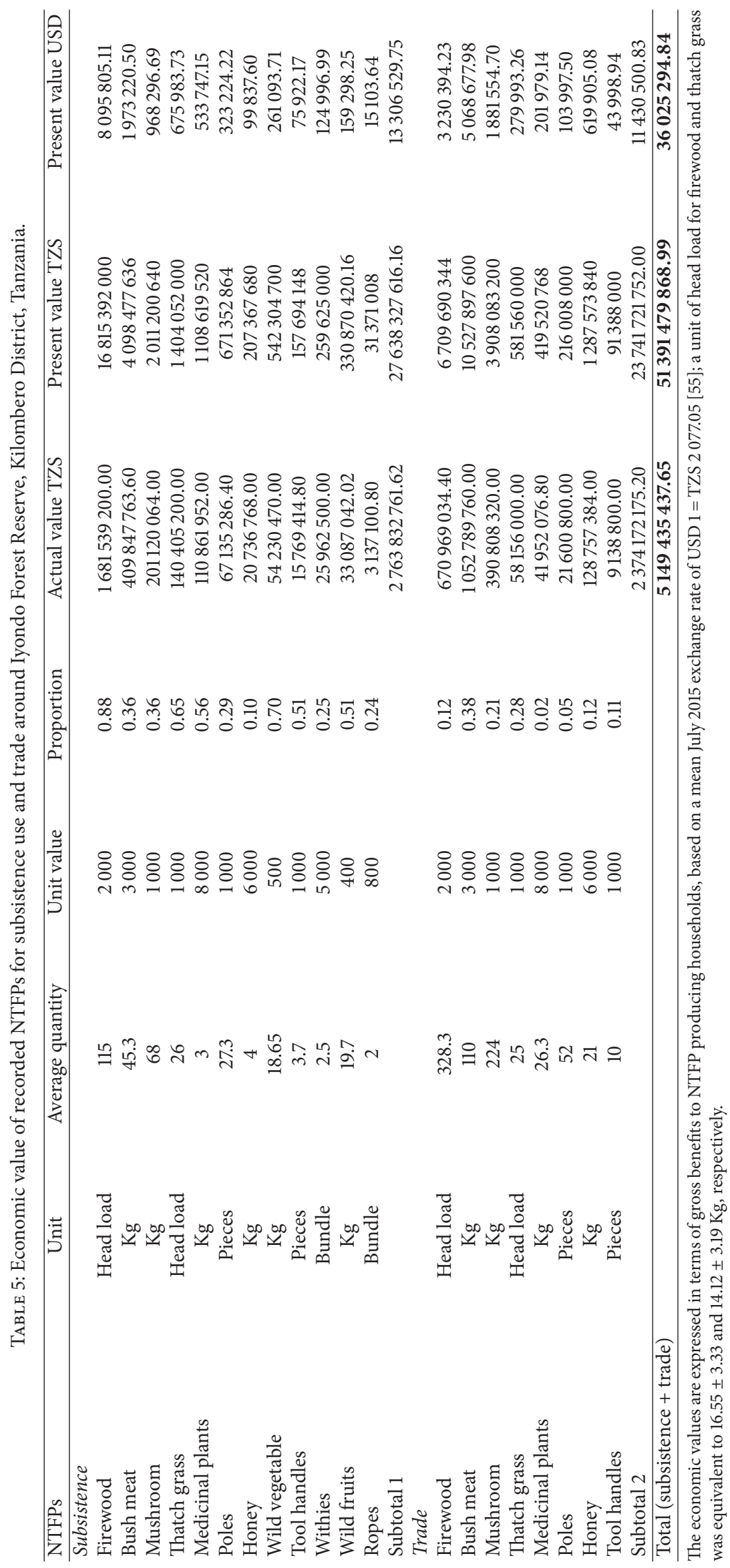


various household needs in the face of changing climate with adverse effects on conversional livelihoods including agriculture. According to Nkem et al. [13], NTFPs are essentially the niche for the poor population, which make them relevant for addressing poverty, health problems, and adaptation to external shocks and stresses due to climate change effects. The findings implied that firewood as part of the natural capital asset had economic value which is significant.

Bush meat was mentioned to be hunted and consumed in the study area. Wild animals that were mostly hunted were puku antelope (Sheshe), bush pigs (Nguruwe pori), and giant pouched rat (Ndezi). The annual present value of bush meat at discounted rate of $10 \%$ was TZS 14.6 billion equivalent to USD 7 million (Table 5). The annual present value recorded in this study was higher than TZS 434450520 reported by Msemwa [46] in Kilosa District. The difference between the two studies could probably be attributed by insufficiency of other sources of meat especially from domestic animals. It was also noted that the unit value of available meat from domesticated animals like cattle was high (TZS 6000 per $\mathrm{kg}$ ), therefore increasing demand of bush meat. Households seem to have adopted various sources of income apart from agriculture to carter for daily human needs.

The annual present value for wild mushroom for subsistence and trade at a discount rate of $10 \%$ was TZS 5.9 billion, which was equivalent to USD 2.8 million (Table 5). The annual present value recorded in this study was higher than TZS 317.7 million (USD 288 841.8) reported by Msemwa [46] in Kilosa District. Similarly, Kilonzo [47] reported annual present value of about 86.3 million (USD 66412 ), which was low compared to the current study. High annual present values recorded in the current study compared to some past studies could probably be due to amount consumed, availability, and use knowledge of the products. High amount of wild mushroom collected was also related to the current changing climate as most of the households earned income that was used for other human needs. Another plausible reason on the difference in amount of wild mushroom consumed can be due to difference in rainfall intensity or pattern and condition of the forests as well as indigenous knowledge. Most of the forests in general land are not well protected and hence highly disturbed for growth of wild mushroom. It has also been reported by Edouard et al. [51] that harvesting of wild mushrooms is likely to be sustainable as long as the habitat of the fungi is not unduly disturbed.

The mean annual present value for thatch grasses for both subsistence use and trade for 8308 households, at a discounting rate of $10 \%$, was estimated at TZS 1.9 billion, which was equivalent to USD 813740.41 (Table 5). The findings from this study are higher than those reported by Schaafsma et al. [28] study in the Eastern Arc Mountains which was about TZS 220 million (USD 0.16 million), probably due to differences in study population size. Another reason could be due to differences in market price, indigenous knowledge, and purpose of collection of the thatch grasses in a particular location. Another plausible reason for the high value of the thatch grasses in the current study could be due to scarcity of the resources especially in Mpofu Villages whereby people collected thatch grasses informally in open areas within the IFR and formally at the Roman Catholic Mission farm in Mbingu Village. High amount of thatch grasses collected were also related to current adverse effects of climate change in the area. Increased temperatures were related to increase in termite activity on thatch grasses in the houses. Also during flooding, houses were demolished, making thatch grasses the immediate roofing materials. The results from the current study were however lower than TZS 7.5 billion (USD 6.8 million) reported by Msemwa [46] in Kilosa District. The difference observed could be due to population size, availability, and the accessibility to the products. The latter study was carried out in general lands of Kilosa District, therefore depicting full access to the products unlike that to the IFR and surrounding environment. According to Schaafsma et al. [25], better enforcement of conservation policies is expected to increase costs of NTFPs collection and therefore reduce extraction levels, either directly through costs of licensing, fines, or bribery or indirectly through the risk premium on illegal collection when avoiding fines. As the study has recognised economic value of the thatch grasses, it is important for households to retain some of the open grasslands that are found within their farms for this purpose. The government should prepare land use management plan that will accommodate some areas thatch grass production.

The annual present value for medicinal plants used for subsistence and trade at a discounting rate of $10 \%$ was TZS 1.5 billion equivalent to USD 735726.29 (Table 5). The annual present value recorded in this study was lower than TZS 3.7 billion (USD 3.3 million) recorded by Msemwa [46] in Kilosa District. The reason behind the differences could be due to population size, accessibility, availability of the products, and religious beliefs, since some respondents associate use of medicinal plants with witchcraft. Free access to forest resources in Kilosa District might have increased the quantity collected and hence there was high annual present value compared to the current study area where there was no free access at to products. On the other hand Kilonzo [47] study in Nyanganje Forest Reserve in Kilombero District reported an annual present value from medicinal plants of TZS 3.3 million (USD 2585). The present study has recorded higher values of annual present values than that by Kilonzo [47]. This could be attributed by the difference in price of the medicinal plants which was TZS 8000 per Kg for present study compared to TZS 500 per $\mathrm{Kg}$ in 2009. The findings imply that medicinal plants have significant economic value that can be contributed to the natural capital asset and its value is increasing daily. Therefore, households should be encouraged to retain on farms some of the tree and shrub species with medicinal values. This will increase availability and therefore serve households against diseases that currently prevail due to adverse effects of climate change effects.

3.4. Factors Influencing Supply of NTFPs at Household Level. Supply of NTFPs was influenced by distance to the forest, change in forest management regime, seasonality, and change in rainfall pattern (Table 6).

About $66 \%$ of respondents agreed that increasing distance to the forest hinders rate of collection of NTFPs (Table 6). The amount of NTFPs collected decreased as distances increased. 
TABLE 6: Factors influencing supply of NTFPs at household level.

\begin{tabular}{lc}
\hline Factors & $\begin{array}{c}{ }^{*} \text { Response }(\%) \\
n=208\end{array}$ \\
\hline Distance to the forest & 66 \\
Change in forest regime & 43 \\
Seasonality & 41 \\
Change in rainfall pattern & 16 \\
\hline
\end{tabular}

${ }^{*}$ Applied multiple response analysis.

This means that opportunity cost of labour time spent for collections increases with distance, implying that people living closer to the forest are more dependent on NTFPs despite the restrictions imposed. Similarly, for households surrounding Nyanganje Forest Reserve, collection of firewood was significantly decreasing with increasing distance [47]. This implied that households residing near IFR still depend more on NTFPs such as firewood and mushroom than those located at distance, in order to increase their adaptive capacity to adverse climate change and vice versa.

In 2007, IFR changed management regime to nature reserve. A nature reserve is the highest category of protected areas which do not allow human consumptive activities [36]. About $43 \%$ of the respondents (Table 6) claimed that limiting access to the forest has decreased the supply of NTFPs at their households, hence increasing their vulnerability to adverse effects of climate change. However in discussion with the forest officer in charge, it was revealed that currently there is informal arrangement that allows households to enter into the forests to collect some nondestructive NTFPs like dried firewood, mushrooms, fruits, and wild vegetables. Therefore, restriction on forest access to promote conservation requires additional policies to prevent a consequent increase in poverty and tradeoff between conservation and extraction of NTFPs [25]. It could be appropriate if surrounding households could be allowed to use the nature reserve for activities which do not pose threat but enhance conservation such as beekeeping. According to Chidumayo [8], activities like beekeeping, collection of firewood, wild fruits, and medicinal plants can be conducted in a reserved forest if carefully planned.

Seasonality was another constraint which hindered collection of NTFPs by $41 \%$ of the respondents (Table 6). Wunder et al. [52] found that seasonality was a substantial constraint during collection of some NTFPs particularly during wet season as physical access was limited. According to Chidumayo [8], increasing temperatures in southern Africa are predicted to either extend the growing season in some ecosystems or shorten it in others. During FGDs it was reported that mushrooms are normally available from February to April. The current growing season has changed because of shift for both short and long rains, therefore affecting yields. Households reported to dry and store mushrooms for some period of time but processing and storage conditions were claimed to be poor. Therefore, mushrooms availability can be improved if adoption of simple but improved technologies of processing and storage could be promoted to households to enhance anticipatory adaptation.

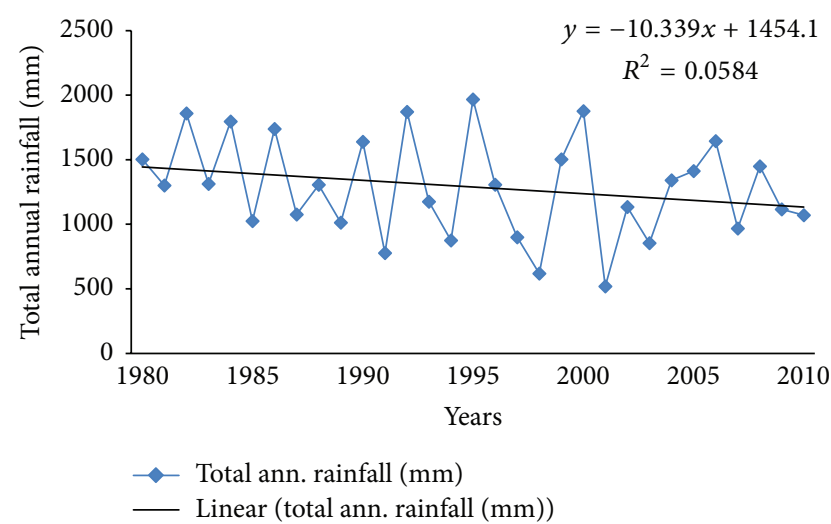

FIGURE 2: Total annual rainfall (mm) recorded between 1980 and 2010 around the study area.

Change of rainfall pattern and intensity has led to lower supply of some NTFPs like mushrooms. Normally in December varieties of mushrooms collected are Amanita zambiana (wilelema) and Termitomyces le-testui (wikulwe), but due to changing of onset and cessation of rainfall in recent years, they are less available. The empirical data showed that rainfall in the study area has been unpredictable (Figure 2).

The rainfall pattern from 1980 to 2010 showed a trend of decrease in total rainfall received for the past three decades. This implied that the study area has been receiving high rains for short period, as was perceived by the majority. Also, from the indigenous knowledge perspective of some respondents, it was reported that prolonged drought has increased the chance of occurrence of wildfire which burns all litters in the forest that form substrate for mushrooms to grow, hence decreasing the supply of mushrooms. Similarly, Chidumayo [8] reported effect of climate change on availability of forest product and services through forest fires which are associated with drought, resulting in biodiversity loss.

During FGDs it was reported that wild mushrooms, thatch grasses, wild vegetables, and bush meet were more sensitive to adverse effects of changing climatic conditions particularly dry spells and floods. Other NTFPs are directly attached to trees found in the natural forests which are more resilient to climate change impacts than monoculture plantations or any artificial forest $[53,54]$. Similarly, Nkem et al. [20] argued that natural forests are less sensitive to climate change effects compared to agricultural crops. Heubes et al. [3] revealed that as NTFPs are mostly derived from plants, their supply is related to the species' occurrence probabilities which might differ from one species to another depending on the sensitivity to adverse effects of changing climatic conditions when other productions circumstances are kept constant.

\section{Conclusion and Recommendations}

4.1. Conclusion. Various NTFPs ranging between food products, firewood, and construction materials were collected for subsistence and traded by households around IFR and village forests and on farms during adverse effects of climate change. 
Collection of NTFPs from the IFR was revealed to be done illegally because of change in management regime from forest reserve to nature reserve. The study has recorded high mean annual value and the economic value of the studied NTFPs from IFR and village forests and on farms. This amount shows the magnitude of the economic loss that households would bear if NTFPs collection was fully and effectively banned in the IFR and the surrounding village forests. The economic value of NTFPs was mainly contributed by firewood, followed by other NTFPs. High contribution of firewood to the economic value is associated with high collection of the product due to daily demand, unlike for other NTFPs. Due to this value the majority of the households seem to rely on firewood as immediate sources of income when conventional livelihood activities were adversely affected by climatic stresses. The main body of understanding has so far focused on the value of prominent forest products like timber and the impacts of climate change on such resources. This empirical documentation of the economic value of priority NTFPs adds to scientific understanding of forest ecosystem based adaptation by showing the potential of NTFPs in increasing adaptive capacity of the households. Last, the supply of NTFPs at household level was influenced by distance to the forests, change in forest management regime, seasonality, and change in rainfall pattern.

4.2. Recommendations. First, change in policies governing forest resources has affected access to the NTFPs in IFR. In this study, this has been regarded as another stress affecting households. Study findings suggest that conservations rules and regulations should be adjusted in order to facilitate access by households to forest resources. Access to the forests by vulnerable populations is as important as the conservation of biodiversity. Access to forests as well as conservation of biodiversity is important to adaptive capacity. The potential synergies and conflicts between these two aspects of NTFPs are managed by rules and regulations, indicating the importance of transforming structures.

Second, the study has documented that households in Kilombero are collecting NTFPs illegally from IFR because the type of management regime does not allow human activities. Together with this, it was as well noted that, within the villages' land, there were remnants of forests that could be managed through formal processes into village forest reserves. Establishment of village forest reserves in which households will have full access is important for sustainable utilization of NTFPs, thus enhancing their adaptive capacity. The study proposes that the established village forest reserves could be managed through community based forest management (CBFM), a management regime that will allow total participation of households in decision making about sustainable forest management.

Third, the study found that households lack skills and knowledge about value addition and marketing of the NTFPs collected. This situation has led to low market value of the products. Capacity building to households on NTFPs value addition and strengthening its markets are pertinent for improved income and eventually increase adaptive capacity to adverse effects of the changing climatic conditions. Also marketing of the products was revealed to be poor as most of the products were sold in isolation at scattered homesteads. This situation might have contributed to low value of the products as most of the traders were not aware of the real market value of the products. From this point of view, capacity building on marketing of the products could include establishment of collection/trading centres in order that it becomes easy for price monitoring as well as control of the quality of the products.

Last, as the NTFPs had high annual economic value, more research could be undertaken to compare economic value of some NTFPs in rainy and dry seasons. Study findings have shown that availability of most of the NTFPs depended on the season. Some of them were reported to be available during rainy season like mushrooms and wild vegetable. Some of the fruits were only available during either rain or dry season. For example, peak season of Tamarind fruits occurred during the dry season when other fruits for making beverages were not available. Households were reported to dry wild fruits for some period of time in order to be used during time of scarcity. Thatch grasses were harvested during dry season, therefore making availability during rainy season be low. The same applies to firewood, as collection was mainly done during dry season rather than in the rainy season. In the rainy season, most households were preoccupied with agricultural activities rather than firewood collection. Season availability of NTFPs was observed to affect market value of the products based on the supply and demand theory. For example, the market value of thatch grasses and firewood was recorded to be high during rainy season compared to dry season. The case is different to mushroom, as it fetched high market value during dry season.

\section{Competing Interests}

The authors declare that they have no competing interests.

\section{Acknowledgments}

The authors thank the Climate Change Impacts Adaptation and Mitigation (CCIAM) Programme, Tanzania, for financial support. They are also highly indebted to the people in Mpofu, Igima, Njage, and Mngeta Villages and other stakeholders in Kilombero District for knowledge sharing and their cooperation during data collection.

\section{References}

[1] B. M. Belcher, "Forest product markets, forests and poverty reduction," International Forestry Review, vol. 7, no. 2, pp. 8289, 2005.

[2] B. Belcher and K. Schreckenberg, "Commercialisation of nontimber forest products: a reality check," Development Policy Review, vol. 25, no. 3, pp. 355-377, 2007.

[3] J. Heubes, K. Heubach, M. Schmidt et al., "Impact of future climate and land use change on non-timber forest product provision in Benin, West Africa: linking niche-based modeling with ecosystem service values," Economic Botany, vol. 66, no. 4, pp. 383-397, 2012. 
[4] I. Niang, O. C. Ruppel, M. A. Abdrabo et al., "Africa," in Climate Change 2014: Impacts, Adaptation, and Vulnerability. Part B: Regional Aspects. Contribution of Working Group II to the Fifth Assessment Report of the Intergovernmental Panel on Climate Change, V. R. Barros, C. B. Field, D. J. Dokken et al., Eds., pp. 1199-1265, Cambridge University Press, Cambridge, UK, 2014.

[5] L. Olsson, M. Opondo, P. Tschakert et al., "Livelihoods and poverty," in Climate Change 2014: Impacts, Adaptation, and Vulnerability. Part A: Global and Sectoral Aspects. Contribution of Working Group II to the Fifth Assessment Report of the Intergovernmental Panel on Climate Change, C. B. Field, V. R. Barros, D. J. Dokken et al., Eds., pp. 793-832, Cambridge University Press, New York, NY, USA, 2014.

[6] J. N. Nkem, O. A. Somorin, C. Jum, M. E. Idinoba, Y. M. Bele, and D. J. Sonwa, "Profiling climate change vulnerability of forest indigenous communities in the Congo Basin," Mitigation and Adaptation Strategies for Global Change, vol. 18, no. 5, pp. 513533, 2013.

[7] P. Rowhani, D. B. Lobell, M. Linderman, and N. Ramankutty, "Climate variability and crop production in Tanzania," Agricultural and Forest Meteorology, vol. 151, no. 4, pp. 449-460, 2011.

[8] E. Chidumayo, "Climate change and the woodlands of Africa," in Climate Change and African Forest and Wildlife Resources, E. Chidumayo, D. Okali, G. Kowero, and M. Larwanou, Eds., pp. 85-101, African Forest Forum, Nairobi, Kenya, 2011.

[9] C. Gordon, The Science of Climate Change in Africa: Impacts and Adaptation, Department for International Development, London, UK, 2008.

[10] S. H. Eriksen, K. Brown, and P. M. Kelly, "The dynamics of vulnerability: locating coping strategies in Kenya and Tanzania," Geographical Journal, vol. 171, no. 4, pp. 287-305, 2005.

[11] J. Paavola, "Livelihoods, vulnerability and adaptation to climate change in Morogoro, Tanzania," Environmental Science and Policy, vol. 11, no. 7, pp. 642-654, 2008.

[12] URT, National Climate Change Strategy, United Republic of Tanzania, Vice President's Office, Division of Environment, Dar es Salaam, Tanzania, 2012.

[13] J. Nkem, F. B. Kalame, M. Idinoba, O. A. Somorin, O. Ndoye, and A. Awono, "Shaping forest safety nets with markets: adaptation to climate change under changing roles of tropical forests in Congo Basin," Environmental Science and Policy, vol. 13, no. 6, pp. 498-508, 2010.

[14] URT, Resource Economic Analysis of Catchment Forest Reserves in Tanzania, Ministry of Natural Resources and Tourism, Forest and Beekeeping Division, Dar es Salaam, Tanzania, 2003.

[15] W. Cavendish, "Empirical regularities in the poverty-environment relationship of rural households: evidence from Zimbabwe," World Development, vol. 28, no. 11, pp. 1979-2003, 2000.

[16] S. K. Pattanayak and E. O. Sills, "Do tropical forests provide natural insurance? The microeconomics of non-timber forest product collection in the Brazilian Amazon," Land Economics, vol. 77, no. 4, pp. 595-612, 2001.

[17] V. Ingram and G. Bongers, Valuation of Non-Timber Forest Product Chains in the Congo Basin: A Methodology for Valuation, FAO-CIFOR-SNV-World Agroforestry CentreCOMIFAC, CIFOR, Yaounde, Cameroon, 2009.

[18] K. Heubach, R. Wittig, E.-A. Nuppenau, and K. Hahn, "Local values, social differentiation and conservation efforts: the impact of ethnic affiliation on the valuation of NTFP-species in Northern Benin, West Africa," Human Ecology, vol. 41, no. 4, pp. 513-533, 2013.
[19] P. Vedeld, A. Angelsen, J. Bojö, E. Sjaastad, and G. Kobugabe Berg, "Forest environmental incomes and the rural poor," Forest Policy and Economics, vol. 9, no. 7, pp. 869-879, 2007.

[20] J. Nkem, H. Santoso, D. Murdiyarso, M. Brockhaus, and M. Kanninen, "Using tropical forest ecosystem goods and services for planning climate change adaptation with implications for food security and poverty reduction," Semi-Arid Tropical Agricultural Research, vol. 4, pp. 1-23, 2007.

[21] J. Sumukwo, A. Wario, M. Kiptui, G. Cheserek, and A. K. Kipkoech, "Valuation of natural insurance demand for nontimber forest products in South Nandi, Kenya," Journal of Emerging Trends in Economics and Management Sciences, vol. 4, no. 1, pp. 89-97, 2013.

[22] C. M. Shackleton and S. E. Shackleton, "The importance of nontimber forest products in rural livelihood security and as safety nets: a review of evidence from South Africa," South African Journal of Science, vol. 100, no. 11-12, pp. 658-664, 2004.

[23] R. P. Neumann and E. Hirsch, Commerciallisation of NonTimber Forest Products: Review and Analysis of the Research, Centre for International Forestry Research, Bogor, Indonesia, 2000.

[24] L. Croitoru, "Valuing the non-timber forest products in the Mediterranean region," Ecological Economics, vol. 63, no. 4, pp. 768-775, 2007.

[25] M. Schaafsma, S. Morse-Jones, P. Posen et al., "The importance of local forest benefits: economic valuation of Non-Timber Forest products in the Eastern Arc Mountains in Tanzania," Ecological Economics, vol. 80, pp. 48-62, 2012.

[26] U. Msalilwa, S. Augustino, and P. R. Gillah, "Community perception on climate change and usage patterns of non-timber forest products by communities around Kilolo District, Tanzania," Ethiopian Journal of Environmental Studies and Management, vol. 6, no. 5, pp. 507-516, 2013.

[27] C. Balama, S. Augustino, S. Eriksen, and F. B. S. Makonda, "Forest adjacent households' voices on their perceptions and adaptation strategies to climate change in Kilombero District, Tanzania," SpringerPlus, vol. 5, article 792, 2016.

[28] M. Schaafsma, S. Morse-Jones, P. Posen et al., "The importance of local forest benefits: economic valuation of non-timber forest products in the eastern Arc mountains in Tanzania," Global Environmental Change, vol. 24, no. 1, pp. 295-305, 2014.

[29] D. W. Pearce and D. Moran, The Economic Value of Biological Diversity, IUCN the World Conservation Union, Earthscan Publications Ltd, London, UK, 1994.

[30] T. Tietenberg and L. Lewis, Environmental and Natural Resource Economics, Peason Education, Upper Saddle River, NJ, USA, 9th edition, 2012.

[31] J. Ferreira, M. Guariguata, L. P. Koh et al., "Impacts of forests and land management on biodiversity and carbon," in Understanding Relationships between Biodiversity, Carbon, Forests and People. The Key to Achieving REDD+ Objectives, J. A. Parrotta and R. L. Trosper, Eds., pp. 53-80, International Union of Forest Research Organization, Vienna, Austria, 2012.

[32] URT (United Republic of Tanzania), Tanzania in Figures 2012, National Bureau of Statistics, Ministry of Finance, Dar es Salaam, Tanzania, 2013.

[33] F. Kato, "Development of a major rice cultivation area in the Kilombero Valley, Tanzania," African Studies Monograph, vol. 36, pp. 3-18, 2007.

[34] A. Chamwali, Survival and Accumulation Strategies at the RuralUrban Interface: A Study of Ifakara Town, Tanzania, Research on Poverty Alleviation, Dar es Salaam, Tanzania, 2000. 
[35] M. Starkey, N. Birnie, A. Cameron et al., The Kilombero Valley Wildife Project: An Ecological and Social Survey in the Kilombero Valley, Tanzania, Kilombero Valley Wildlife Project, Edinburgh, UK, 2002.

[36] P. Harrison, Socio-Economic Study of Forest-Adjacent Communities from Nyanganje Forest to Udzungwa Scarp: A Potential Wildlife Corridor. Incorporating Livelihood Assessments and Options for Future Management of Udzungwa Forests, World Wide Fund (WWF) for Nature, Dar es Salaam, Tanzania, 2006.

[37] NBS, "Shapefiles-Level one and two," 2012, http://www.nbs.go .tz/.

[38] T. E. Erlanger, A. A. Enayati, J. Hemingway, H. Mshinda, A. Tami, and C. Lengeler, "Field issues related to effectiveness of insecticide-treated nets in Tanzania," Medical and Veterinary Entomology, vol. 18, no. 2, pp. 153-160, 2004.

[39] M. A. W. Hetzel, S. Alba, M. Fankhauser et al., "Malaria risk and access to prevention and treatment in the paddies of the Kilombero Valley, Tanzania," Malaria Journal, vol. 7, article 7, 2008.

[40] J. C. Lovett and T. Lovett and Pocs, Assessment of the Condition of the Catchment Forest Reserves, a Botanical Appraisal, Morogoro Region, 1993.

[41] P. Barribeau, B. Butler, J. Corney et al., "Survey Research," 2015, http://writing.colostate.edu/guides/pdfs/guide68.pdf.

[42] G. C. Monela, S. A. O. Chamshama, R. Mwaipopo, and D. M. Gamasa, A Study on the Social, Economic and Environmental Impacts of Forest Landscape Restoration in Shinyanga Region, Tanzania, Forestry and Beekeeping Division of the Ministry of Natural Resources and Tourism, of Tanzania, and IUCN-The World Conservation Union Eastern Africa Regional Office, Dar es Salaam, Tanzania, 2005.

[43] S. Morse-Jones, T. Luisetti, R. K. Turner, and B. Fisher, "Ecosystem valuation: some principles and a partial application," Environmetrics, vol. 22, no. 5, pp. 675-685, 2011.

[44] F. Dolisca, D. R. Carter, J. M. McDaniel, D. A. Shannon, and C. M. Jolly, "Factors influencing farmers' participation in forestry management programs: A case study from Haiti," Forest Ecology and Management, vol. 236, no. 2-3, pp. 324-331, 2006.

[45] A. Tazeze, J. Haji, and M. Ketema, "Climate change adaptation strategies of smallholder farmers: the case of Babilie District, East Harerghe Zone of Oromia Regional State of Ethiopia," Journal of Economics and Sustainable Development, vol. 3, no. 14, pp. 1-13, 2012.

[46] S. C. Msemwa, Economic valuation of forests on general land in Kilosa District, Tanzania [M.S. dissertation], Sokoine University of Agriculture, Morogoro, Tanzania, 2007.

[47] M. Kilonzo, Valuation of non-timber forest products used by communities around Nyanganje Forest Reserve, Morogoro, Tanzania [M.S. dissertation], Sokoine University of Agriculture, Morogoro, Tanzania, 2009.

[48] I. S. Masam, Contribution of non-timber forest products to the livelihoods of communities living adjacent to New Dabaga Ulongambi Forest Reserve, Kilolo District [M.S. thesis], Sokoine University of Agriculture, Morogoro, Tanzania, 2009.

[49] K. F. S. Hamza, U. L. Msalilwa, and R. J. L. Mwamakimbullah, "Contribution of some Non-Timber Forest Products (NTFPs) to household food security and income generation: a case study of villages around Mgori Forest Reserve in Singida, Tanzania," Journal of Tanzania Association of Foresters, vol. 11, pp. 11-22, 2007.

[50] T. Paulo, The contribution of non-timber forest products in improving livelihood of rural community in Kilwa District,
Tanzania [Dissertation for Award of MSc. Degree], Sokoine University of Agriculture, Morogoro, Tanzania, 2007.

[51] F. Edouard, Q. Raday, and E. Marshall, "Fresh, dried and exported mushrooms: community business and entrepreneurs," in Commercialization of Non-timber Forest Products: Factors Influencing Success. Lessons Learned from Mexico and Bolivia and Policy Implications for Decision Makers, E. Marshal, K. Schrecken Berg, and A. C. Newton, Eds., pp. 49-52, UNEP World Conservation Monitoring Centre, Cambridge, UK, 2006.

[52] S. Wunder, J. Börner, G. Shively, and M. Wyman, "Safety nets, gap filling and forests: a global-comparative perspective," World Development, vol. 64, no. 1, pp. S29-S42, 2014.

[53] P. Smith, M. Bustamante, H. Ahammad et al., "Agriculture, Forestry and Other Land Use (AFOLU)," in Climate Change 2014: Mitigation of Climate Change. Contribution of Working Group III to the Fifth Assessment Report of the Intergovernmental Panel on Climate Change, O. Edenhofer, R. Pichs-Madruga, Y. Sokona et al., Eds., pp. 811-922, Cambridge University Press, Cambridge, UK, 2014.

[54] N. H. Ravindranath, "Mitigation and adaptation synergy in forest sector," Mitigation and Adaptation Strategies for Global Change, vol. 12, no. 5, pp. 843-853, 2007.

[55] Bank of Tanzania, "Bank of Tanzania (BoT)," 2015, https://www .bot-tz.org/. 

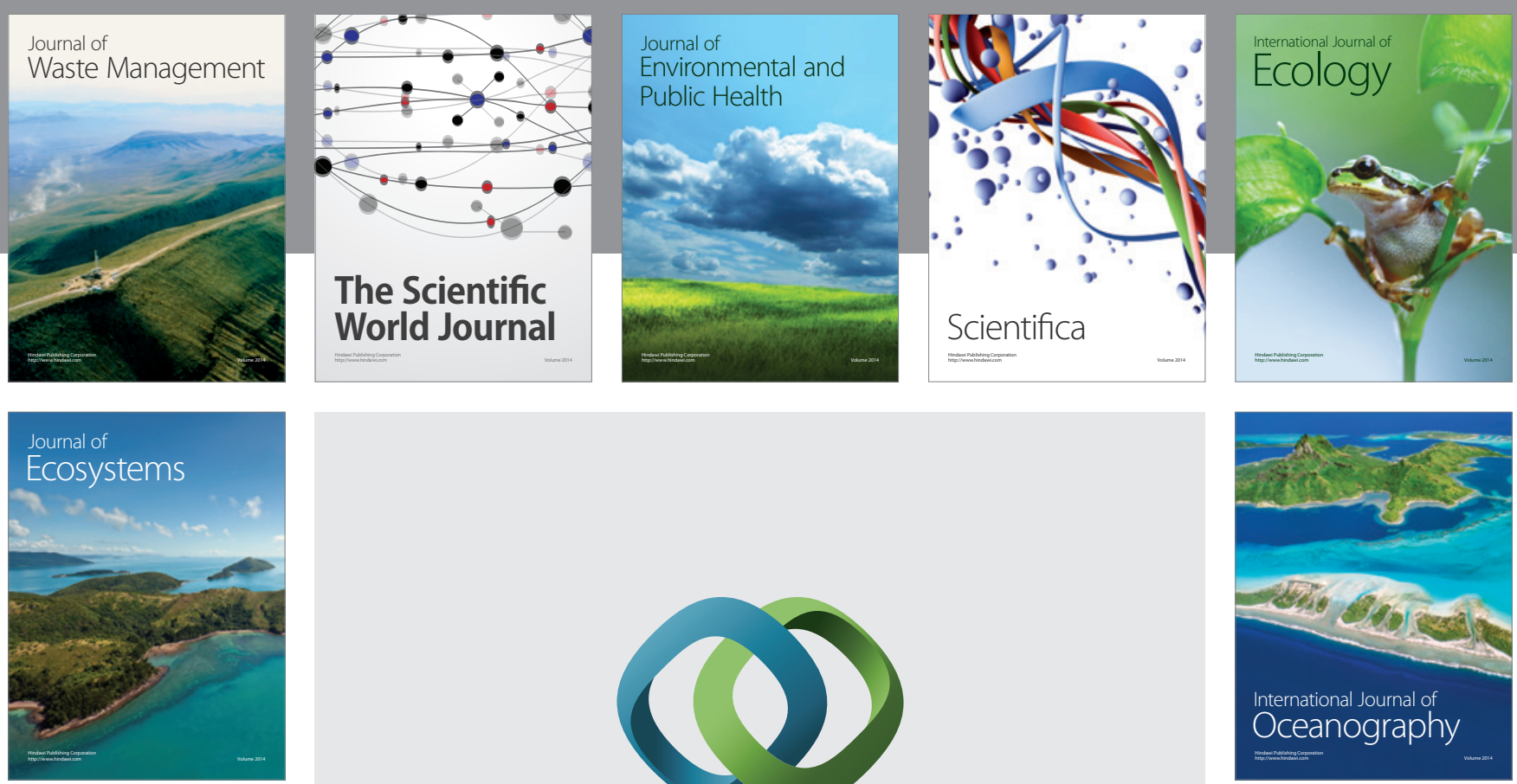

The Scientific World Journal
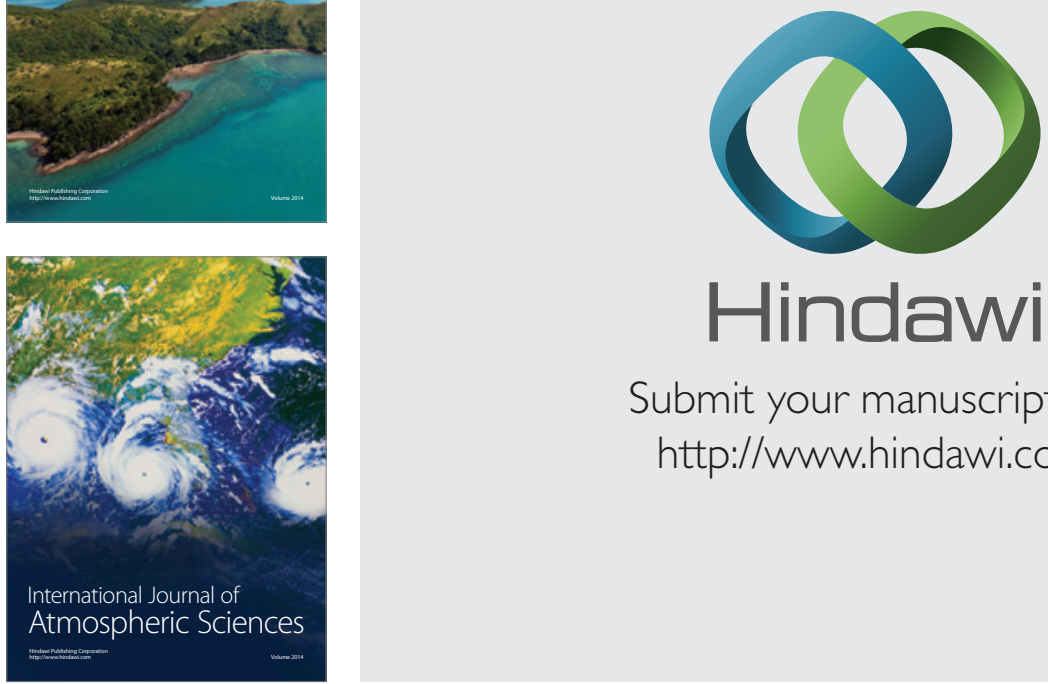

\section{Hindawi}

Submit your manuscripts at

http://www.hindawi.com
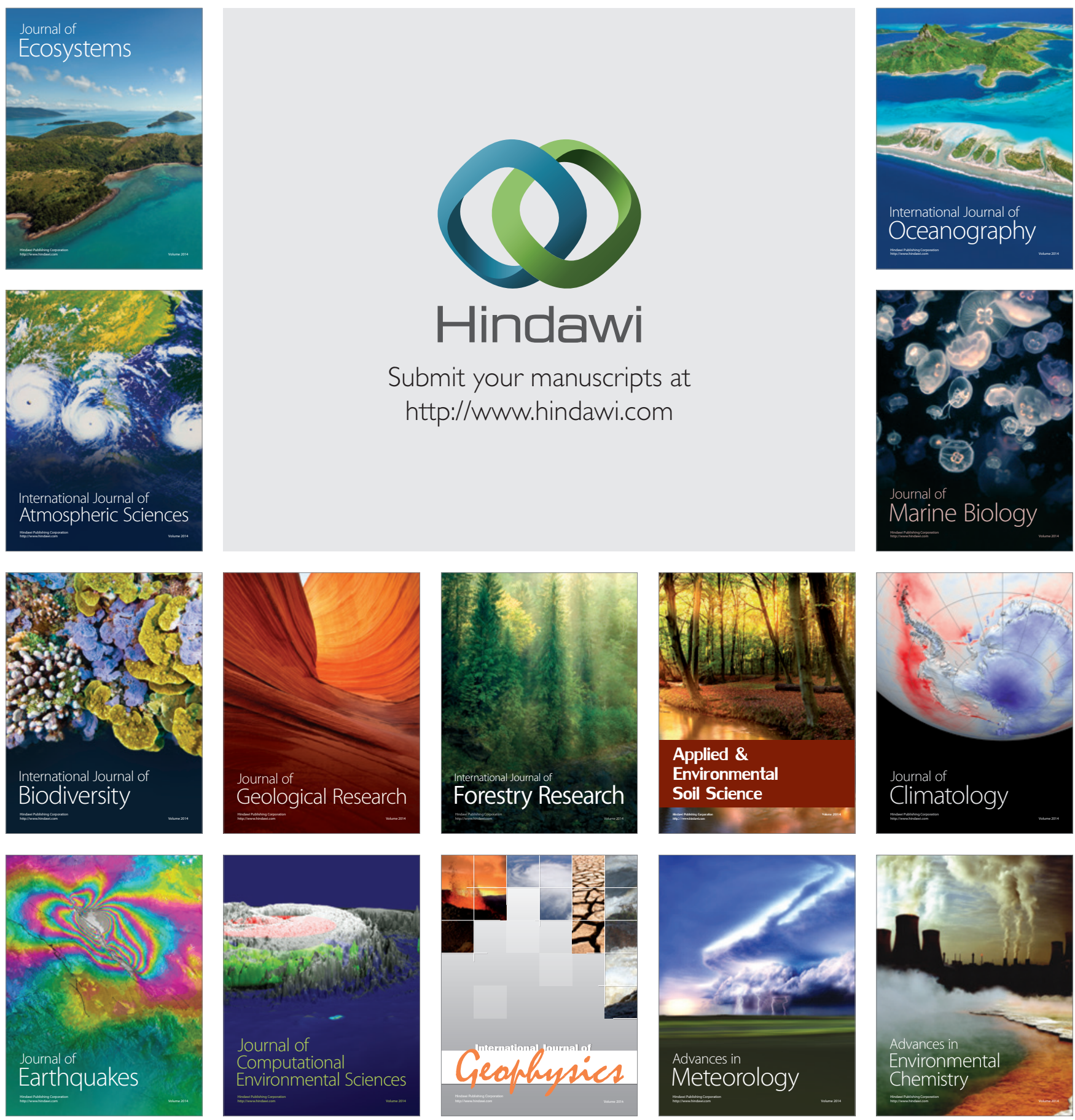